International Journal of Social Sciences and Humanities
Available online at www.sciencescholar.us
Vol. 5 No. 3, December 2021, pages: 214-222
e-ISSN: 2550-7001, p-ISSN: 2550-701X
https://doi.org/10.53730/ijssh.v5n3.2026

\title{
Influence of Internal Communication and Work Discipline on Performance of Employees at the Health Department of Lubuk Linggau City
}

\begin{abstract}
(C) CrossMark
\author{
Chrisman Frans Perdamean a , Isnurhadi ${ }^{b}$, Zunaidah $^{c}$, Agustina Hanafi ${ }^{\mathrm{d}}$
}

Manuscript submitted: 27 September 2021, Manuscript revised: 09 October 2021, Accepted for publication: 18 November 2021

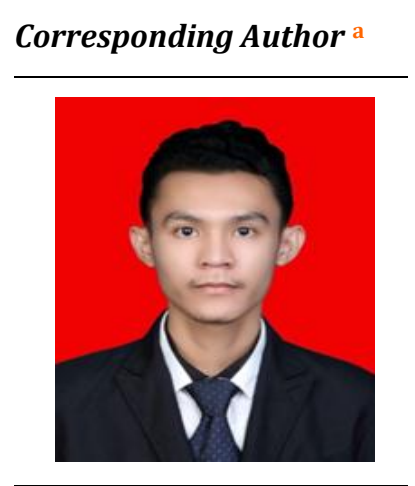

Keywords

employee performance; health department; internal communication; positive effect; work discipline;

Abstract

This study aimed to determine and analyze whether internal communication and work discipline have a positive and significant effect on the performance of the Lubuk Linggau City Health Office employees. The population in this study was all Lubuk Linggau City Health Office employees, amounting to 50 people. The sampling technique in this study used a saturated sample technique with 50 respondents that used primary data obtained through questionnaires and multiple linear regression analysis methods as data analysis techniques. The results showed that internal communication had a positive and significant effect on the performance of the Lubuk Linggau City Health Office employees, work discipline had a positive and significant impact on the performance of Lubuk Linggau City Health Office employees, and internal communication and work discipline together had a positive and significant impact on the performance of the Health Office employees. Lubuk Linggau City and internal communication are the most dominant variables affecting the performance of Lubuk Linggau City Health Office employees. It is hoped that internal communication at the Lubuk Linggau City Health Office can continue to evaluate to achieve effective internal communication, and work discipline can be maintained to maintain the institution's stability and harmony.
\end{abstract}

International Journal of Social Sciences and Humanities (C) 2021. This is an open access article under the CC BY-NC-ND license (https://creativecommons.org/licenses/by-nc-nd/4.0/).

\footnotetext{
${ }^{a}$ Master of Management, Sriwijaya University, Palembang, Indonesia

b Lecturer of Magister Management, Economic Faculty, Sriwijaya University, Palembang, Indonesia

c Lecturer of Magister Management, Economic Faculty, Sriwijaya University, Palembang, Indonesia

${ }^{d}$ Lecturer of Magister Management, Economic Faculty, Sriwijaya University, Palembang, Indonesia
} 


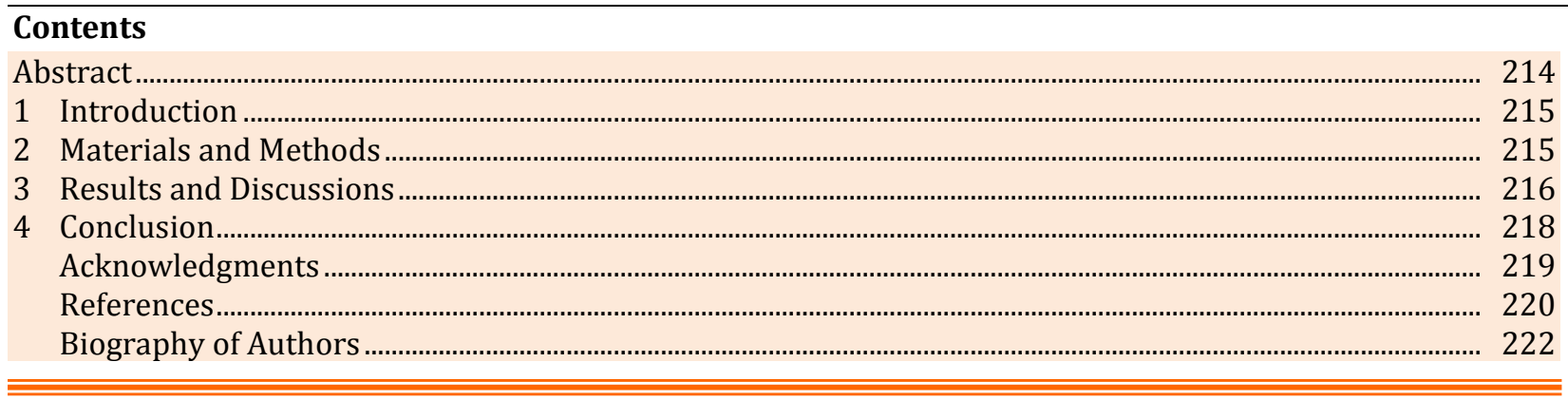

\section{Introduction}

Agencies need to manage human resources as well as possible because the key to an agency's success is technological excellence and the availability of funds, but the human factor is the most crucial. Internal communication is an internal organizational process that presents and shares to form a sense of togetherness and trust between employees, according to Robbins \& Judge (2017). Every agency needs professional, competent, trusted, and diligent resources. Employees whom the agency later expects can provide good performance to help the development of the agency itself, without good performance in all fields within the agency, the success of an agency becomes very difficult to realize or even impossible to realize (Negara \& Anwar, 2005).

A significant influence between Internal Communication and Employee Performance is in line with Ahmad (2016), opinion that Communication and Work Discipline will increase employee performance. With effective communication and high work discipline, it is hoped that the performance produced by employees can increase so that the agency's goals can be achieved. Ritonga et al. (2021), states that internal communication has a positive and significant effect on employee performance. This study supports the research results from previous studies, which found a significant influence between Internal Communication and Employee Performance. This is in line with Husain (2018), with the title "The Effect of Work Discipline on Employee Performance (At PT. Bank Danamon Tbk Bintaro Branch). Putra \& Liswani (2020), states that Work Discipline has a positive and significant relationship to employee performance. In contrast to Amar's (2018), research on TVRI employees in East Java, it was found that Internal Communication had no significant effect on employee performance.

The phenomena of problems at the Lubuk Linggau City Health Office related to employee work discipline include some employees who are often late to the office. This is due to the weakness of punitive sanctions for employees who arrive late, especially coupled with the daily attendance that is used still using attendance with a manual system, in addition to this phenomenon of work discipline problems that occur, namely that several employees go home outside of predetermined working hours (Permatasari \& Ratnawati, 2021). Moreover, there are still employees who do not entirely work following predetermined standards and time, and also, there is still excessive use of free time at work. Discipline problems certainly significantly affect employee performance. Therefore, the application of discipline to employees will improve the performance of the employees themselves. The purpose of this study is to analyze how Internal Communication and Work Discipline have a positive and significant effect on the Performance of the Lubuk Linggau City Health Service Employees and analyze which variables have the dominant influence on the Lubuk Linggau City Health Service Employee Performance (Ruck \& Welch, 2012; Verčič \& Špoljarić, 2020).

\section{Materials and Methods}

The design of this research is the entire series of processes carried out, starting from planning, implementing research to collecting processed data as the final result of the research. The research will be carried out using an explanatory survey design, conducting field observations to explain the collected data, which is then analyzed using quantitative methods that test hypotheses based on existing data and the theories/opinions

Perdamean, C. F., Isnurhadi, I., Zunaidah, Z., \& Hanafi, A. (2021). Influence of internal communication and work discipline on performance of employees at the health department of Lubuk Linggau City. International Journal of Social Sciences and Humanities, 5(3), 214-222. https://doi.org/10.53730/ijssh.v5n3.2026 
used (Phillippi \& Lauderdale, 2018; Porter et al., 2016; Brinkman-Kealey, 2012; Holliday, 2010; Morse, 2015; Marshall et al., 2013; Bengtsson, 2016; Punch, 2013). This research will determine the effect of the independent variables (X1 and $\mathrm{X} 2$ ) on the dependent variable $(\mathrm{Y})$ with the size of their respective indicators so that the study will examine in more depth the variables used.

\section{Results and Discussions}

Table 1

Multiple linear regression analysis results

\begin{tabular}{clccc}
\hline & & \multicolumn{2}{c}{ Unstandardized Coefficients } & Standardized Coefficients \\
\cline { 3 - 5 } Model & & $\mathrm{B}$ & Std. Error & Beta \\
\hline \multirow{2}{*}{1} & (Constant) & 4.925 & 1.252 & \\
& Internal Communication & .313 & .099 & .584 \\
& Work Discipline & .287 & .136 & .391 \\
\hline
\end{tabular}

\section{$Y=4.925+0.313 X 1+0.287 X 2+e$}

a) The constant value (a) is 4.925, meaning that the Lubuk Linggau City Health Service Employee Performance is 4.925 units with the assumption that the Inten Communication and Work Discipline variables are currently in a constant or fixed state (value " $0 "$ ).

b) Internal Communication regression coefficient value (b 1) is 0.313 . This shows that if Internal Communication increases by 1 unit, then the Performance $(Y)$ of the Lubuk Linggau City Health Service Employees will directly increase by 0.313 .

c) The regression coefficient value of Work Discipline (b 2) is 0.287 . This shows that if work discipline increases by 1 unit, then the Performance $(\mathrm{Y})$ of the Lubuk Linggau City Health Service Employees will directly increase by 0.287 .

Table 2

Result of correlation coefficient ( $\mathrm{r}$ ) and coefficient of determination $\left(\mathrm{R}^{2}\right)$

\begin{tabular}{lllll}
\hline Model & R & R Square & Adjusted R Square & Std. The error of the Estimate \\
\hline 1 & $.971^{\mathrm{a}}$ & .943 & .940 & 1,635 \\
\hline
\end{tabular}

Based on the results above, it can be seen that the value of $r$ as the correlation coefficient is 0.971 . This figure can be interpreted that Internal Communication and Work Discipline have a solid relationship or closeness to affect the Performance of the Lubuk Linggau City Health Service Employees. Meanwhile, the value of $\mathrm{R}$ Square as the coefficient of determination $\left(\mathrm{R}^{2}\right)$ is 0.943 . The coefficient of determination illustrates that the variable Communications Intern (X 1 ) and Work Discipline (X 2 ) capable of affecting the performance (Y) Health Bureau staff Lubuklinggau amounted to $94.3 \%$. In comparison, the remaining $5.7 \%$ is influenced by other variables not included in this research model, such as motivation, work environment, leadership, compensation, and others.

Table 3

F test (Model Feasibility Test)

\begin{tabular}{lllllll}
\hline Model & & Sum of Squares & df & Mean Square & F & Sig. \\
\hline 1 & Regression & 2058,910 & 2 & 1029,455 & 385,256 & $.000^{\mathrm{b}}$ \\
& Residual & 125.590 & 47 & 2,672 & & \\
& Total & 2184,500 & 49 & & & \\
\hline
\end{tabular}


Based on the results of the analysis of the $\mathrm{F}$ test (ANOVA) in table 4.18, the calculated $\mathrm{F}$ value with $\mathrm{N}=50$ is 385.256 . Based on these results, the calculated $\mathrm{F}$ value is 385.256 greater than the $\mathrm{F}$ - table value $(\mathrm{df}=1: 47)$ at the 95\% confidence level, which is 3.195 ( F- count $385.256>\mathrm{F}$ - table 3.195 ) the significance probability level $\mathrm{F}=$ 0.000 is smaller than Alpha 0.05 (Sig $0.000<0.05$ ). The conclusion that Ha Ho accepted and rejected, meaning that the variable Communications Intern (X1) and Work Discipline (X 2 ) have a significant effect on the performance variable $(\mathrm{Y})$ Health Bureau staff Lubuk Linggau.

Table 4

Individual parameter significance test (t-Test)

\begin{tabular}{lllllll}
\hline & & \multicolumn{2}{l}{$\begin{array}{l}\text { Unstandardized } \\
\text { Coefficients }\end{array}$} & \multicolumn{2}{l}{$\begin{array}{l}\text { Standardized } \\
\text { Coefficients }\end{array}$} & \\
\cline { 3 - 5 } Model & & B & Std. Error & Beta & t & Sig. \\
\hline \multirow{2}{*}{1} & (Constant) & 4.925 & 1.252 & & 3,935 & .000 \\
& Internal & .313 & .099 & .584 & 3.147 & .003 \\
& Communications (X 1) & & & & & \\
& Work Discipline (X 2) & .287 & .136 & .391 & 2.105 & .041 \\
\hline
\end{tabular}

a) The results of the t-test of the Internal Communication variable (X1) on Employee Performance (Y) show a sig value of 0.000 which means the significance value is smaller than the probability value of $0.05(0.000<0.05)$, and $t$ - count shows a value of 3.935 , meaning that the $t$ - value count $>t-$ table value $(3.935$ $>1.677)$. This shows that Internal Communication has a positive and significant effect on Employee Performance.

b) Results of Work Discipline t-test variable (X 2 ) on employee performance (Y) showed sig 0.041, which means a significant value smaller than the probability value of $0.05(0.041<0.05)$, and $t$ count showed 2,105 means that the value of $t$ count $>t-$ table value $(2.105>1.677)$. This shows that work discipline has a positive and significant effect on employee performance.

c) This means that the first hypothesis is accepted where Internal Communication and Work Discipline affect the Performance of the Lubuk Linggau City Health Service Employees. This means that Employee Performance can be explained significantly by the variables of Internal Communication and Work Discipline.

d) The most dominant variable affecting employee performance is a Communications Intern for valuebeta $(\beta) 0.584$ more significant than the beta ( $\beta$ ) 0.391 Work Discipline variable. This indicates that the second hypothesis is accepted where Communications Intern has a more significant influence on employee performance Lubuklinggau City Health Department. The third hypothesis is rejected because the value of beta $(\beta)$ Work Discipline is smaller than that of value beta $(\beta)$ Communications Intern.

The results showed that the Communications Intern (X1) had a significant and positive effect on employee performance (Y). This is in line with the statement of Robbins \& Judge (2017). Communication is used to provide feedback to people in power, provide them with information about achieving goals and convey current problems. Managers use upward communication to get ideas on how to improve performance. This study also supports the results of previous studies, which found a significant influence between Internal Communication and Employee Performance. This is in line with Ahmad (2016), opinion that Communication and Work Discipline will increase employee performance. With effective communication and high work discipline, it is hoped that the performance produced by employees can increase so that the agency's goals can be achieved. Amyulianthy \& Ritonga (2016), state that internal communication has a positive and significant effect on employee performance.

So internal communication is needed by every employee, especially at the Lubuk Linggau City Health Office, to improve the effectiveness of carrying out tasks, delivering information, and creating better relationships between fellow employees in carrying out their work to be able to provide the best service to improve performance to achieve agency goals. The results of the t-test for the Work Discipline variable (X2) in this study found no significant effect of the variable Work Discipline on employee performance. Thus, if work

Perdamean, C. F., Isnurhadi, I., Zunaidah, Z., \& Hanafi, A. (2021). Influence of internal communication and work discipline on performance of employees at the health department of Lubuk Linggau City. International Journal of Social Sciences and Humanities, 5(3), 214-222. https://doi.org/10.53730/ijssh.v5n3.2026 
discipline increases, employee performance will also increase significantly, and vice versa if work discipline decreases, employee performance will also decrease significantly (Jo \& Shim, 2005; Hu \& Liu, 2020).

The ANOVA test or $\mathrm{F}$ test shows that the variables of Internal Communication and Work Discipline simultaneously affect employee performance, which means that employee performance can be explained significantly by the variables of Internal Communication and Work Discipline. This study also suggests that the most dominant variable affecting employee performance is a Communications Intern for value beta $(\beta)$ 0.584 more significant than beta ( $\beta$ ). The work Discipline variable has a probability of 0.391 and 0.000 . This means that the indicators of the Internal Communication variable have a more significant or dominant influence on the performance of the Lubuk Linggau City Health Service Employees (Van Dolen et al., 2004; Diantari \& Riana, 2019).

The results of the analysis of the frequency distribution of respondents to the indicator of the source, message, media, receiver, effect, responsive turning, and the environment in a variable Communications Intern (X1), it can be concluded that the majority of respondents agreed with the statements related indicators of Communications Intern (X1) with a combined percentage of respondents' agreement of $60 \%$. However, there are still statements that do not agree with the Lubuk Linggau City Health Service employees with a percentage of $18 \%$, namely about the delivery of messages or instructions in the form of orders or rules from the leadership that is not understood by employees so that the messages conveyed by the leadership do not affect their attitudes. This can impact employee behavior, ranging from delaying work, being absent, or being absent on workdays to decreased productivity and performance (Mangkunegara \& Waris, 2015; Güngör, 2011).

The results of the analysis of the frequency distribution of responses responded of indicators timeliness, utilization of facilities, the responsibility is high, and adherence to the rules of the office in the variable Work Discipline (X2) can be concluded that the majority of respondents agreed with the statements related indicators Work Discipline (X2) with a combined percentage of respondents' agreement of $72 \%$. This shows that Lubuk Linggau City Health Service employees have high work discipline against agency rules; high work discipline creates a sense of responsibility towards the agency to improve performance.

The results of the analysis of the frequency distribution of respondents' responses to indicators of work quality, work quantity, implementation of duties and responsibilities in the Performance variable (Y) above, it can be concluded that most respondents agree with statements related to Performance indicators (Y) with a combined percentage of respondents' approval of $58 \%$. However, some statements do not agree with a percentage of only $13 \%$. This can disrupt the performance of the Lubuk Linggau City Health Service Employees in carrying out their operational activities and can affect the level of employee productivity (Eliyana \& Ma'arif, 2019; Osman et al., 2016).

\section{Conclusion}

Based on the description of the research results, the conclusions that can be drawn to answer the formulation of the problem in this study are:

a) Internal Communication has a positive and significant effect on Employee Performance

b) Work Discipline has a positive and significant effect on Employee Performance

c) The most dominant variable influencing employee performance in this study is Internal Communication

Based on the results of the analysis and discussion in this study, the suggestions that can be given are:

a) Internal Communications at the Lubuk Linggau City Health Office would continue to evaluate and improve the quality of communication to create effective communication. This research is aimed at the back office division were to improve work discipline through internal communication from superiors to subordinates. 
b) Work Discipline at the Lubuk Linggau City Health Office is expected to be improved to several divisions with low work discipline. In this case, some employees in the back office division to maintain the agency's stability and harmony to improve performance to achieve employee goals.

c) The performance at the Lubuk Linggau City Health Office is quite good, but it must maintain performance standards to improve and maintain employee productivity. Divisions with declining performance can improve performance by communicating between superiors and subordinates and looking for problems that occur in divisions or individuals who have decreased performance.

\section{Acknowledgments}

The authors would like to thank do all supports and financial support from both from university and the government of the Republic of Indonesia. Without this support, this paper will not be done as planned.

Perdamean, C. F., Isnurhadi, I., Zunaidah, Z., \& Hanafi, A. (2021). Influence of internal communication and work discipline on performance of employees at the health department of Lubuk Linggau City. International Journal of Social Sciences and Humanities, 5(3), 214-222. https://doi.org/10.53730/ijssh.v5n3.2026 


\section{References}

Ahmad, S. (2016). Pengaruh Komunikasi dan Disiplin Kerja terhadap Kinerja Pegawai PT BNI (Persero) TBK Sentra Kredit Konsumen Palembang. Program Studi Magister Manajemen Universitas Sriwijaya Palembang, Indonesia.

Amar, A. (2018). Pengaruh komunikasi internal dan kepemimpinan terhadap kinerja karyawan TVRI Jawa Timur (Doctoral dissertation, UIN Sunan Ampel Surabaya).

Amyulianthy, R., \& Ritonga, E. K. (2016). The Effect Of Economic Value Added And Earning Per Share To Stocks Return (Panel Data Approachment). International Journal of Business and Management Invention, 5(2), 815.

Bengtsson, M. (2016). How to plan and perform a qualitative study using content analysis. NursingPlus Open, 2, 8-14. https://doi.org/10.1016/j.npls.2016.01.001

Brinkman-Kealey, R. (2012). A qualitative phenomenological analysis exploring digital immigrants' use of church-based computer-supported collaborative learning (Doctoral dissertation, University of Phoenix).

Diantari, N. P. A., \& Riana, I. G. (2019). Effect of transformational leadership and compensation on employee performance. International Research Journal of Management, IT and Social Sciences, 6(6), 146-154. https://doi.org/10.21744/irjmis.v6n6.781

Eliyana, A., \& Ma'arif, S. (2019). Job satisfaction and organizational commitment effect in the transformational leadership towards employee performance. European Research on Management and Business Economics, 25(3), 144-150. https://doi.org/10.1016/j.iedeen.2019.05.001

Güngör, P. (2011). The relationship between reward management system and employee performance with the mediating role of motivation: A quantitative study on global banks. Procedia-Social and Behavioral Sciences, 24, 1510-1520. https://doi.org/10.1016/j.sbspro.2011.09.029

Holliday, A. (2010). Analysing qualitative data. Continuum companion to research methods in applied linguistics, 98-110.

Hu, Y., \& Liu, L. (2020). Becoming industrious female citizens: Work, discipline, and negotiation in Chinese female prison. International Journal of Law, Crime and Justice, 63, 100420. https://doi.org/10.1016/j.ijlcj.2020.100420

Husain, B. A. (2018). Pengaruh Disiplin Kerja Terhadap Kinerja Karyawan (Pada PT. Bank Danamon Tbk Cabang Bintaro). Jurnal Disrupsi Bisnis, 1(1).

Jo, S., \& Shim, S. W. (2005). Paradigm shift of employee communication: The effect of management communication on trusting relationships. Public relations review, 31(2), $277-280$. https://doi.org/10.1016/j.pubrev.2005.02.012

Mangkunegara, A. P., \& Waris, A. (2015). Effect of training, competence and discipline on employee performance in company (case study in PT. Asuransi Bangun Askrida). Procedia-Social and Behavioral Sciences, 211, 1240-1251. https://doi.org/10.1016/j.sbspro.2015.11.165

Marshall, B., Cardon, P., Poddar, A., \& Fontenot, R. (2013). Does sample size matter in qualitative research?: A review of qualitative interviews in IS research. Journal of computer information systems, 54(1), 11-22.

Morse, J. M. (2015). Critical analysis of strategies for determining rigor in qualitative inquiry. Qualitative health research, 25(9), 1212-1222.

Negara, M., \& Anwar, P. (2005). Evaluasi Kinerja Sumber Daya Manusia.

Osman, S., Shariff, S. H., \& Lajin, M. N. A. (2016). Does innovation contribute to employee

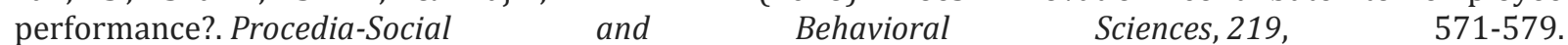
https://doi.org/10.1016/j.sbspro.2016.05.036

Permatasari, J., \& Ratnawati, I. (2021). Work climate and employee performances: a literature observation. International Research Journal of Management, IT and Social Sciences, 8(2), 184-195. https://doi.org/10.21744/irjmis.v8n2.1425

Phillippi, J., \& Lauderdale, J. (2018). A guide to field notes for qualitative research: Context and conversation. Qualitative health research, 28(3), 381-388.

Porter, W. W., Graham, C. R., Bodily, R. G., \& Sandberg, D. S. (2016). A qualitative analysis of institutional drivers and barriers to blended learning adoption in higher education. The internet and Higher education, 28, 17-27.

Punch, K. F. (2013). Introduction to social research: Quantitative and qualitative approaches. sage. 
Putra, S., \& Liswani, E. (2020). The Influence of Discipline and Work Environment on Employees' Performance. Jurnal Ilmu Manajemen, 10(1), 25-32.

Ritonga, M., Sartika, F., \& Kustati, M. (2021). Madrasah al-Ula for Children: An Effective Learning Management in the Family during Covid-19 Pandemic. Ilkogretim Online-Elementary Education Online, 20(1), 968-976.

Robbins, S. P., \& Judge, T. A. (2017). Perilaku Organisasi (Cetakan Kelima).

Ruck, K., \& Welch, M. (2012). Valuing internal communication; management and employee perspectives. Public relations review, 38(2), 294-302. https://doi.org/10.1016/j.pubrev.2011.12.016 Verčič, A. T., \& Špoljarić, A. (2020). Managing internal communication: How the choice of channels affects internal communication satisfaction. Public relations review, 46(3), 101926. https://doi.org/10.1016/j.pubrev.2020.101926

Van Dolen, W., De Ruyter, K., \& Lemmink, J. (2004). An empirical assessment of the influence of customer emotions and contact employee performance on encounter and relationship satisfaction. Journal of Business research, 57(4), 437-444. https://doi.org/10.1016/S0148-2963(02)00277-1

Perdamean, C. F., Isnurhadi, I., Zunaidah, Z., \& Hanafi, A. (2021). Influence of internal communication and work discipline on performance of employees at the health department of Lubuk Linggau City. International Journal of Social Sciences and Humanities, 5(3), 214-222. https://doi.org/10.53730/ijssh.v5n3.2026 


\section{Biography of Authors}

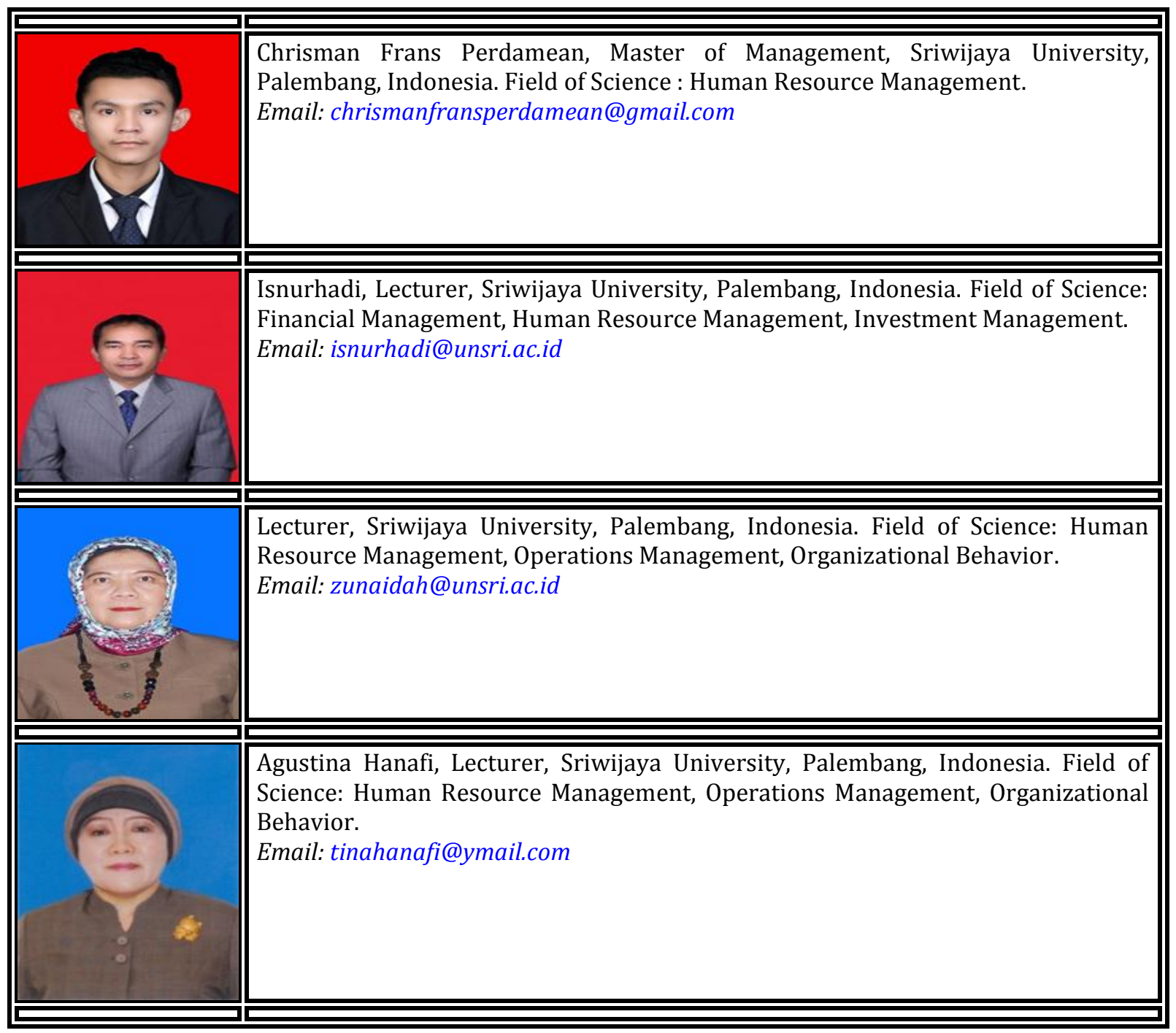

